\title{
Evaluation of Different Coloured Varieties of Grapes under Nontraditional Area of Malwa Plateau: A Thin Line Tool for Doubling the Farmer Income
}

\author{
Nitin Soni, Prakash Patil, K.C. Meena, Ajay Haldar*, \\ Dharmendra K. Patidar and Rajesh Tiwari
}

\author{
RVSKVV, AICRP on Fruits (Grapes), College of Horticulture, \\ Mandsaur (M.P.)-458001, India
}

*Corresponding author

\section{Key w o r ds \\ Grapes, Coloured varieties, Malwa \\ Plateau and \\ Doubling Farmers income \\ Article Info \\ Accepted: \\ 15 February 2019 \\ Available Online: \\ 10 March 2019}

\section{A B S T R A C T}

Malwa Plateau is nontraditional area of grapes and the investigations was conducted at experimental field of AICRP on Fruits (Grapes), College of Horticulture, Mandsaur from year 2014-15 to 2017-18 for popularizing the grapes cultivating area and exploring the climatic condition of the region for coloured table grapes cultivation (hot day and cold night up to March - April with low humidity). There were ten grapes varieties under the evaluation study, i.e. Sharad Seedless, Krishna Seedless, Flame Seedless, A-18/3, Fantasy Seedless, Kishmish Moldowsky, Black Seedless, Kishmish Rozavis Red, Crimson Seedless and Ruby Seedless. Fruit skin colour was observed red in Krishna Seedless, Flame Seedless, Kishmish Moldowsky, Kishmish Rozavis Red, Crimson Seedless and Ruby Seedless. The Sharad Seedless, Fantasy Seedless, A-18/3 and Black Seedless observed black fruit skin colour. The shape of Flame Seedless, Kishmish Moldowsky, Ruby Seedless and Black Seedless varieties observed round and six varieties i.e. Kishmish Rozavis Red, Crimson Seedless, A-18/3, Krishna Seedless, Sharad Seedless and Fantasy Seedless fund oval in shape. The early maturity was observed in Flame Seedless (134 days after fruit pruning). Maximum yield $(6.23 \mathrm{~kg}$ ) was recorded in A-18/3 with small bunch size i.e. $99.27 \mathrm{~g}$ and maximum number of bunch i.e. 61.13 bunches per vine, similarly the Kishmish Moldowsky recorded maximum bunch weight $211.81 \mathrm{~g}$ with maximum beery weight (283.69 gm/100 berries). Whereas variety flame seedless recorded maximum TSS $25^{\circ} \mathrm{B}$ with minimum acidity i.e. $0.44 \%$.

\section{Introduction}

Grapes cultivation is performed in wide climate regimes worldwide that provide optimum situations to produce high quality grapes (De Blij, 1983). Most of the world's viticulture regions are located between latitudes of $40^{\circ}$ and $50^{\circ} \mathrm{N}$ in northern hemisphere and between latitudes of $30^{\circ}$ and $40^{\circ} \mathrm{S}$ in the southern hemisphere called as temperate climatic belt (Iland et al., 2009). Grapes growing in tropical regions have been performed commercially since approximately 50 years (Jogaiah et al., 2013). There are 
numerous grapes growing regions between the tropic of Capricorn and the tropic of Cancer, in tropical zone. The tropic of Cancer and the tropic of Capricorn refer to that part of the earth that lays between $23^{\circ}$ North and South Latitudes. The Tropic of Cancer is located at $23^{\circ}$ North of the Equator and runs through Mexico, the Bahamas, Egypt, Saudi Arabia, India and Southern China. The Tropic of Capricorn lies at $23^{\circ}$ South of the Equator and runs through Australia, Chile, Southern Brazil and Northern South Africa. Among the countries with tropical climatic conditions, it can be seen that Brazil, India, Thailand and Venezuela play an important roles in the tropical grapes production in the world extends in various countries of different continents in Bolivia, Colombia, Peru, Guatemala (in South America), in Madagascar, Namibia, Tanzania (in Africa) and in Vietnam, China (in Asia) (Jogaiah et al., 2013).

In India, grapes are grown under tropical and semi-arid irrigated regions in North India condition as well as in Central, Southern and Coastal Tropical Regions. Madhya Pradesh is nontraditional area of grapes cultivation and has huge potential for grape industries in state particularly in Malwa Plateau. Madhya Pradesh is part of peninsular plateau of India lying in North Central part. The boundary can be decided by Gangetic plains in the North, in the West by the Aravali range, Chhattisgarh plain in East and Tapti valley and the Plateau of Maharashtra in the South. In Madhya Pradesh, a study of rainfall pattern shows that the comparative weather in south west monsoon is chiefly responsible for the successful cultivation of grapevine under Malwa Plateau. In Malwa Plateau region year divides into three seasons: summer, rainy and winter. Summers extends over the month of mid-March to end May i.e. Chaitra to Jyestha. The average temperature during summer rages between $35-37{ }^{\circ} \mathrm{C}$, which typically rises to around $40{ }^{\circ} \mathrm{C}$ in May month for few days. The rainy season starts form mid to end of the June to the middle of September. Most of the rain falls during the southwest monsoon spell. Areas like Mandsaur and Susner receive less than $80 \mathrm{~cm}$ of rainfall. Ujjain, Indore, Dhar and most other areas receive slightly higher rainfall (between $85 \mathrm{~cm}$ and $110 \mathrm{~cm}$ ). In the region winter is the longest among three seasons which extend about five months from October to mid- March. The average daily temperature of the season ranges between $5^{\circ} \mathrm{C}$ to $20{ }^{\circ} \mathrm{C}$, though on some nights it can fall as low as $7{ }^{\circ} \mathrm{C}$ and frost.

These conditions are favorable for growing coloured varieties of grapes in region because the hot day and cold nights are help to developing colour pigments like anthocyanin, similarly low humidity in the month of December to April helps to increase in TSS (Romeyer et al., 1983) and Jackson and Lombard 1993). The optimal temperatures for anthocyanin accumulation in grapes berries are in the range $15-25^{\circ} \mathrm{C}$ during the date day time and the night temperature $10-20^{\circ} \mathrm{C}$ (Kliewer and Toores, 1972). With the above mentioned facts an experiment conducted to study the evaluation and characterization of coloured grapes varieties under Malwa Plateau.

\section{Materials and Methods}

The experiment of coloured grapes varieties characterization was conducted during the year 2014-15 to 2017-18 at research field of College of Horticulture, Mandsaur, under AICRP on Fruits (Grapes). The data was analyzed with Randomized Block Design with ten treatments and four replication.

\section{Experimental Protocol}

Grapes varieties (total ten varieties) i.e. Sharad Seedless, Krishna Seedless, Flame Seedless, 
A-18/3, Fantasy Seedless, Kishmish Moldowsky, Black Seedless, Kishmish Rozavis Red, Crimson Seedless and Ruby Seedless were collected from NRC Grapes, Pune. These grapes varieties were evaluated by characterization study on training system of 'Y trellis' type with spacing of $3 \times 2 \mathrm{~m}^{2}$. The age of plant was eight year. All management practices like irrigation, hoeing, pesticide spray etc, were managed accordingly as routine manner. Data was collected for following variables and statistically analyzed.

\section{Growth attributes}

Cane girth $(\mathbf{m m})$ : The mature cane girth majored by vernier caliper five branches in per plant for observation.

Mature canes/vine: Total mature canes were counted per plant for observation.

Fruitful canes/vine: Total number of fruitful canes/vine were identified by flower bud and counted.

\section{Phenological attributes}

Panicle appearance (Days): The panicle appearance was observed on the basis of day after fruit pruning.

Days to anthesis: The flower opening (days to anthesis) was observed on the basis of day after fruit pruning.

Days to fruit set: The days to fruit set was observed on the basis of days after fruit pruning.

Days to fruit ripening: The days to fruit ripening was observed on the basis of day after fruit pruning.

Berry length (mm): Size of grapes berry length was determined with the help of vernier caliper.
Berry diameter (mm): Size of grapes berry diameter was determined with the help of vernier caliper.

Number of bunches/vine: Number of bunch of grapes was determined by counting number of bunches per vine.

Bunch weight (g): The weight of grapes bunch was determined by digital balance.

Yield (kg/vine): The yield per vine was determined by digital balance.

Berry weight (g): Weight of one berry recorded by digital balance.

Weight of 100 berries (g): Weight of 100 berries recorded by digital balance.

Quality attributes (TSS and Acidity \%)

TSS ( $\left.{ }^{0} \mathbf{B}\right)$ : TSS $\left({ }^{0} \mathrm{~B}\right)$ were majored by refractometer in berries recorded by digital balance

Acidity (\%): The acidity ratio (\%) determined through titration of $\mathrm{NaOH}$ and phenolphthalein using of this formula.

Titrate X Acid Factor X 100

Percentage Acid $=$

$$
10 \text { (ml Juice) }
$$

\section{Organoleptic attributes}

Organoleptic evaluation of fruit was recorded for berry colour and berry texture and berry aroma and test.

\section{Results and Discussion}

\section{Growth attributes}

Present findings revealed that the maximum cane girth was found in variety Ruby Seedless 
(99.26 mm), followed by variety Sharad Seedless $(92.23 \mathrm{~mm})$ and variety Black Seedless $(89.54 \mathrm{~mm})$, while the minimum cane girth was found in variety Flame Seedless $(75.32 \mathrm{~mm})$ respectively. The mature canes/vine in four years observation data was presented given in table (1) reviled that the maximum mature canes/vine was found in variety Crimson Seedless (47.38), which was at par with variety Kishmish Rozavis Red (39.44), followed by variety Sharad Seedless (36.19), while the minimum mature canes/vine was found in variety Kishmish Moldowsky (22.13), respectively. The observation shown that maximum fruitful canes/vine was found in variety Crimson Seedless (27.19), which was at par with variety A- 18/3 (22.31), followed by variety Flame Seedless (16.56), while the minimum fruitful canes/vine was found in variety Fantasy Seedless (5.81), respectively.

Highly vigorous varieties which strengthen our present finding that high pruning weight may result in more number of canes giving rise to more vigorous vines. Similar findings were reported by Pina and Bautists (2006) in grape for pruning weight and girth of main trunk and girth of stem and Joshi et al., (2015) in grape for pruning weight and number of canes per vine.

\section{Phenological attributes}

In phenological attribute, on the basis of four year observation panicle appearance (Days) observe maximum (20.81 days) in variety Sharad Seedless and variety A- 18/3 (18 days) take minimum time to panicle appearance observed respectively. In respect of day to anthesis the maximum days to anthesis taken in Krishna Seedless (40.06 days) and minimum in Black seedless (36.68 days) respectively. Four year data of days to fruit set reviled that the maximum days taken for days to fruit set found in Kishmish Rozavis Red (48.18 days) and minimum in Black Seedless
(45.81 days). Days taken for bud burst vary from variety to variety and climatic conditions. The time taken for bud burst is taken as an index to classify the grape varieties as early, mid and late varieties (Mandelli et al., 2003). Kumar et al., (2015) in papaya for days to flowering. Days taken to $50 \%$ fruit set ranged from 37.00 to 52.33 with a mean of 46.88 . The weather plays a vital role in fertilization of a grape crop. Similar findings were reported by Huang and $\mathrm{Lu}$ (2000) for bud breaking and flower opening in Muscadine grape, Uddin et al., (2011) for days to fruit setting. Similar result report by Gupta et al., (2015) for bud burst, panicle initiation, flowering and fruit set in grapes.

In case of days to fruit ripening the mean of four years data shows that the minimum days to fruit ripening was found in variety Flame Seedless (134 days), while the maximum days to fruit ripening was found in variety Crimson Seedless (155 days). The heat unit requirement ranged from 1547.5 to 2201.6 with a mean of 1719.3. The stage of maturity can be judged by heat summation. Hence, heat unit requirement for maturity in different cultivars was worked out based on the base temperature of grape. Varieties exhibit inherent differences in their heat unit requirement. Each variety has a specific heat summation requirement which however, varies under the influence of climatic condition and time. The requirements of heat units also differed with earliness or lateness of the variety. The variation in the heat unit requirement with the variation in the date of maturity was also reported in Grapes (Thakur et al., 2008) and Mango (Shinde et al., 2001).

On the basis of mean of four years data was revealed that maximum berry length was found in variety Sharad Seedless $(20.25 \mathrm{~mm})$, followed by Fantasy Seedless $(19.84 \mathrm{~mm})$ and A- 18/3 (19.12 mm), while the minimum berry length was found in variety Crimson Seedless 
$(16.14 \mathrm{~mm})$ and Flame Seedless $(16.18 \mathrm{~mm})$ respectively. The variation in the berry weight might be due to variation in the diameter of the berries and also due to number of berries per bunch. Similar observation also noted by Thakur et al., (2008).

The Berry diameter $(\mathrm{mm})$ mean of four years conclude that, the maximum berry diameter was found in variety Flame Seedless (16.22 $\mathrm{mm})$, followed by variety Fantasy Seedless $(15.11 \mathrm{~mm})$ and Black Seedless $(15.44 \mathrm{~mm})$, while the minimum berry diameter was found in variety Kishmish Rozavis Red (12.69 mm). The high berry diameter may be due to presence less number of berries in a bunch, if more berries are present in the bunch may lead to less diameter of the grape berries. Kadu et al., (2007) reported the similar findings with different wine varieties.

The four year mean of Number of bunches/vine was presented in table. The maximum number of bunches/vine was found in variety A-18/3 (61.13), which was at par with Black Seedless (44.25), followed by variety Flame Seedless (36.63), while the minimum number of bunches/vine was found in variety Ruby Seedless (8.75). The increased number of bunches per vine increases the grape yield per vine with an increment in carbohydrate content in the canes to the maximum extent. A wide range in number of bunches was reported by several workers 9.30 to 33.43 (Kadu et al., 2007), 17.35 to 93.10 (Karibasappa and Adsule, 2008), 58.33 to 142.00 (Ratnacharyulu, 2010), 131 to 162 (Walker et al., 2000).

The maximum bunch weight was found in variety Kishmish Moldowsky (211.81 g), which was at par with Black Seedless (168.45 g) and variety Sharad Seedless (152.36 g), followed by variety Krishna Seedless (136.10 $\mathrm{g}$ ), while the minimum bunch weight was found in variety A-18/3 (99.27 g), respectively. The bunch weight also differed in cultivars of grape viz., Cabernet Franc (147.7 g), Ugni Blanc (135.6g), Chenin Blanc (132.8g) as reported by Havinal et al., (2008).

In case of Yield ( $\mathrm{kg} / \mathrm{vine})$, the maximum yield was found in variety A-18/3 (6.23 kg/vine), which was at par with Kishmish Moldowsky (4.41 kg/vine), followed by variety Flame Seedless (4.04 kg/vine), while the minimum yield was found in variety Ruby Seedless (1.18 kg/vine), respectively. The difference in the yield per vine in different grape cultivars might be due to differences in weight of the bunch, number of bunches, weight of the berries and age of the vines, nutrition, cultural practices adopted, pest and disease incidence besides their successful adoption to the varying agro-climatic conditions under which they are cultivated Wide range of yield among different varieties of grape screened at different location has been reported by Kadu 2002; Shellie 2007; Karibasappa and Adsule 2008; Havinal et al., 2008 and Ratnacharyulu, 2010 which support the results.

Observation of Berry weight $(\mathrm{g})$ revealed that the maximum Berry weight was found in variety Kishmish Moldowsky (2.83 g), which was at par with Fantasy Seedless (2.56 g), variety Black Seedless (2.35 g) and variety Crimson Seedless (2.34 g), followed by variety A-18/3 (2.19 g), while the minimum berry weight was found in variety Kishmish Rozavis Red (1.53 g), respectively. Similarly Weight of 100 berries was found in variety Kishmish Moldowsky (283.69 g g), which was at par with Fantasy Seedless (256.75 g), variety Black Seedless (234.88 g g) and variety Crimson Seedless (233.81 g), followed by variety A-18/3 (219.13 g), while the minimum Weight of 100 berries was found in variety Ruby Seedless (180.38 g), respectively. Wide range of hundred berry weight was reported by several workers, 104 to $275 \mathrm{~g}$ (Ram Kumar et al., 2002), 106 to 403 
(Ratnacharyulu, 2010), 130 to $480 \mathrm{~g}$ (Thakur et al., 2008).

\section{Quality attributes}

The maximum TSS was found in variety Flame Seedless $\left(25^{0} \mathrm{~B}\right)$, followed by variety Sharad Seedless $\left(24.94{ }^{0} \mathrm{~B}\right)$ and variety Kishmish Rozavis Red $\left(24.19^{0} \mathrm{~B}\right)$, while the minimum TSS was found in variety Black Seedless $\left(21^{0} \mathrm{~B}\right)$.

The maximum Acidity was found in variety Kishmish Moldowsky (0.58 \%), followed by variety Kishmish Rozavis Red (0.54 \%), while the minimum Acidity was found in variety Sharad Seedless $(0.43 \%)$, respectively. The biochemical (SSC, TA, sugars, amino acids, organic acids, phenolic compounds \& total antioxidants) attributes of table grapes varieties can be vary with change in the site, locality, topography and environment. Similar observation was also noted by Mattheou et al., (1995), Thakur et al., (2008) and Khan et al., (2011).

\section{Organoleptic attributes}

Organoleptic evaluation of fruit was recorded for berry colour and berry texture and berry aroma. The berry taste of fruits ranged from very sweet, sweet and sour. The colour of berries ranged in two group from black to purple and red to dark pink. The shape of berry considered under the character oval, round and long.

Berry taste: Among ten genotypes, eight grape varieties (Sharad Seedless, Krishna Seedless, Flame Seedless, Kishmish Red, Crimson Seedless, Ruby Seedless) falls under very sweet category and two varieties (A-18/3, Fantasy Seedless, Kishmish moldowsky) under sweet category.

Berry aroma: On the basis of berry aroma nine varieties i.e. Sharad Seedless, Krishna Seedless, Flame Seedless, A-18/3, Fantasy Seedless, Black Seedless, Kishmish Rozavis Red, Crimson Seedless, Ruby Seedless fall under musky group and Kishmish Moldowsky variety in flavorless group.

Berry texture: Among the ten varieties, nine varieties were categorized as juicy viz: Sharad Seedless, Krishna Seedless, Flame Seedless, A-18/3, Kishmish Moldowsky, Black Seedless, Kishmish Rozavis Red, Crimson Seedless, Ruby Seedless, whereas the Fantasy Seedless variety falls into soft category.

Table.1 Organoleptic attributes of coloured varieties of grapes

\begin{tabular}{|l|l|l|l|l|}
\hline Varieties & Berry Taste & Berry Colour & $\begin{array}{l}\text { Berry } \\
\text { Texture }\end{array}$ & Berry Aroma \\
\hline Sharad Seedless & Very sweet & Purple & Juicy & Musky \\
\hline Krishna Seedless & Very sweet & Dark Pink & Juicy & Musky \\
\hline Flame Seedless & Very sweet & Dark Pink to Red & Juicy & Musky \\
\hline A- 18/3 & Sweet & Black & Juicy & Musky \\
\hline Fantasy Seedless & Sweet & Purple to Black & Soft & Musky \\
\hline Kishmish Moldowsky & Sweet & Dark Pink to Red & Juicy & Flavorless \\
\hline Black Seedless & Sweet & Black & Juicy & Musky \\
\hline Kishmish Rozavis Red & Very sweet & Dark Pink to Red & Juicy & Musky \\
\hline Crimson Seedless & Very sweet & Dark Pink to Red & Juicy & Musky \\
\hline Ruby Seedless & Very sweet & Dark Pink to Red & Juicy & Musky \\
\hline
\end{tabular}


Table.2 Coloured variety of grapes germplasms characterization on the basis of growth attributes, Phenological attributes and Quality attributes

\begin{tabular}{|c|c|c|c|c|c|c|c|c|}
\hline Varieties & $\begin{array}{l}\text { Cane } \\
\text { Girth } \\
(\mathbf{m m})\end{array}$ & $\begin{array}{c}\text { Mature } \\
\text { canes/ } \\
\text { vine }\end{array}$ & $\begin{array}{c}\text { Fruitful } \\
\text { canes/ } \\
\text { Vine }\end{array}$ & $\begin{array}{l}\text { Panicle } \\
\text { appearan } \\
\text { ce (days) }\end{array}$ & $\begin{array}{l}\text { Days to } \\
\text { anthesis }\end{array}$ & $\begin{array}{l}\text { Days to } \\
\text { fruit } \\
\text { set }\end{array}$ & $\begin{array}{c}\text { Days to } \\
\text { fruit } \\
\text { ripening }\end{array}$ & $\begin{array}{c}\text { Berry } \\
\text { length } \\
(\mathrm{mm})\end{array}$ \\
\hline Sharad Seedless & 92.22 & 36.18 & 15.00 & 20.81 & 38.25 & 47.81 & 145.25 & 20.25 \\
\hline Krishna Seedless & 82.66 & 33.50 & 10.94 & 20.44 & 40.06 & 47.62 & 151.50 & 18.94 \\
\hline Flame Seedless & 75.32 & 30.88 & 16.56 & 20.00 & 38.00 & 47.93 & 134.00 & 16.18 \\
\hline A- 18/3 & 82.61 & 33.06 & 22.31 & 18.00 & 39.87 & 47.31 & 148.00 & 19.12 \\
\hline Fantasy Seedless & 89.39 & 24.75 & 5.81 & 20.94 & 38.68 & 46.50 & 147.00 & 19.84 \\
\hline $\begin{array}{l}\text { Kishmish } \\
\text { Moldowsky }\end{array}$ & 58.99 & 22.13 & 9.81 & 19.06 & 38.81 & 46.87 & 150.25 & 18.70 \\
\hline Black Seedless & 89.54 & 37.50 & 26.25 & 19.63 & 36.68 & 45.81 & 146.75 & 18.72 \\
\hline $\begin{array}{l}\text { Kishmish Rozavis } \\
\text { Red }\end{array}$ & 83.90 & 39.44 & 12.63 & 19.94 & 38.93 & 48.18 & 149.00 & 16.61 \\
\hline Crimson Seedless & 85.31 & 47.37 & 27.19 & 20.75 & 38.25 & 47.37 & 155.00 & 14.55 \\
\hline Ruby Seedless & 99.26 & 27.06 & 7.00 & 19.88 & 38.00 & 47.25 & 154.00 & 18.58 \\
\hline S.Em. \pm & 2.26 & 2.83 & 3.65 & 0.67 & 1.01 & 0.72 & 3.09 & 1.79 \\
\hline CD at $5 \%$ & 6.58 & 8.23 & 10.61 & NS & NS & NS & 8.97 & NS \\
\hline
\end{tabular}

Table.3 Coloured variety of grapes germplasms characterization on the basis of growth attributes, Phenological attributes and Quality attributes

\begin{tabular}{|c|c|c|c|c|c|c|c|c|}
\hline Varieties & $\begin{array}{c}\text { Berry } \\
\text { diameter } \\
(\mathbf{m m})\end{array}$ & $\begin{array}{c}\text { Number } \\
\text { of } \\
\text { bunches } \\
\text { /vine }\end{array}$ & $\begin{array}{c}\text { Bunch } \\
\text { weight } \\
\text { (g) }\end{array}$ & $\begin{array}{c}\text { Yield } \\
\text { (kg/vi } \\
\text { ne) }\end{array}$ & $\begin{array}{c}\text { Berry } \\
\text { weight } \\
\text { (g) }\end{array}$ & $\begin{array}{l}\text { Weight } \\
\text { of } 100 \\
\text { berries } \\
\text { (g) }\end{array}$ & $\begin{array}{l}\text { TSS } \\
\left({ }^{\circ} \mathbf{B}\right)\end{array}$ & $\begin{array}{c}\text { Acidity } \\
(\%)\end{array}$ \\
\hline Sharad Seedless & 15.40 & 14.81 & 152.35 & 2.29 & 2.09 & 209.87 & 24.93 & 0.43 \\
\hline Krishna Seedless & 13.08 & 13.62 & 136.09 & 1.99 & 1.84 & 183.87 & 23.31 & 0.47 \\
\hline Flame Seedless & 16.22 & 36.62 & 117.82 & 4.03 & 1.94 & 193.87 & 25.00 & 0.44 \\
\hline A-18/3 & 14.76 & 61.12 & 99.26 & 6.22 & 2.19 & 219.12 & 23.12 & 0.52 \\
\hline Fantasy Seedless & 15.10 & 10.93 & 112.32 & 1.30 & 2.56 & 256.74 & 21.75 & 0.50 \\
\hline Kishmish Moldowsky & 17.90 & 19.18 & 211.81 & 4.41 & 2.83 & 283.68 & 22.62 & 0.57 \\
\hline Black Seedless & 15.43 & 44.25 & 83.10 & 3.92 & 2.35 & 234.87 & 21.00 & 0.53 \\
\hline Kishmish Rozavis Red & 12.68 & 18.87 & 108.03 & 1.92 & 1.52 & 152.68 & 24.18 & 0.53 \\
\hline Crimson Seedless & 13.81 & 18.68 & 101.72 & 2.31 & 2.34 & 233.81 & 21.31 & 0.48 \\
\hline Ruby Seedless & 14.82 & 8.75 & 168.45 & 1.18 & 1.77 & 180.37 & 22.56 & 0.47 \\
\hline S.Em. \pm & 0.64 & 7.04 & 23.46 & 0.71 & 0.18 & 18.66 & 1.22 & 0.0090 \\
\hline CD at $5 \%$ & 1.85 & 20.43 & 68.08 & 2.06 & 0.54 & 54.16 & 3.54 & 0.0262 \\
\hline
\end{tabular}

Berry skin colour: Berry skin colour was observed red to dark pink in Krishna Seedless, Flame Seedless, Kishmish Moldowsky, Kishmish Rozavis Red, Crimson
Seedless and Ruby Seedless and Purple to black Sharad Seedless, Fantasy Seedless, A18/3 and Black Seedless. 
Shape of berry: The shape of Flame Seedless, Kishmish Moldowsky, Ruby Seedless and Black Seedless varieties observed round and six varieties i.e. Kishmish Rozavis Red, Crimson Seedless, A-18/3, Krishna Seedless, Sharad Seedless and Fantasy Seedless fund oval in shape. The above Organoleptic evaluations were supported by Khan et al., (2011). Similarly Kumar et al., (2010) recorded similar results for fruit appearance, flavour and taste and Uddin et al., (2011) in grape for fruit taste and colour.

In conclusion, the present investigation for elite type of coloured grape varieties that have variability exists with regard to different growth, phenological, fruit yield, quality and organoleptic attribute of fruit. On the basis of four year research, It is concluded that: among the ten coloured verities "Flame Seedless" was found early maturity variety and A-18/3 found most suitable because it is an medium maturing seedless variety having excellent taste, attractive black colour, large size berries and high yielding. Whereas the Kishmish Moldowsky variety, which have attractive red colour, maximum bunch weight and good fruit size and quality have great market potential.

\section{References}

De Blij, H.J., 1983. Geography of Viticulture: Rationale and resource. J. Geog. 112121.

Gupta, N., Gill, K.K., Babuta, R., Gill, M., and Arora, N.K. 2015. Thermal requirement and phonological development of different grape varieties under South-Western Punjab. Ann. Agric. Res. 36 (4): 377- 383.

Huang, H., and Lu, J. 2000. Variation and correlation of bud breaking, flower opening and fruit ripening in Muscadine grape cultivars. Proc. Fla. State Hort.
Soc. 113: 46-47.

Iland, P., Gago, P., Caillard, A. and Dry, P., 2009. A Taste of the World of Wine. Patric Iland Wine Promotions, Adelaide, South Australia.

Jackson, D.I., and Lombard, P.B. 1993. Environmental and management practices affecting grape composition and wine quality a review. Am. J. Enol. Vitic., 44: 409-430.

Jogaiah, S., Oulkar, D.P., Vijapure, A.N., Maske, S.R., Sharma, A.K. and Somkuwar, R.G. 2013. Influences of canopy management practices on fruit composition of wine grape cultivars grown in Semi-Arid tropical region of India. African Journal of Agricultural Research, 8 (26):3462- 3472.

Joshi, V., Kumar, V., Debnath, M., Pattanashetti, S., Variath, M.T., and Khadakabhavi, S. 2015. Multivariate analysis of coloured and white grape under semi arid tropical conditions of Peninsular India. I. J. A. C. S., 8(2): 350-365.

Kadu, S.Y., Tambe, T.B., and Patil, S.P. 2007. Studies on leaf morphology and vine vigour of various grape wine varieties. The Asian Jr. Hort., 2(1): 131134.

Karibasappa, G.S. and Adsule, P.G. 2008. Evaluation of wine grape genotypes by National Research centre for Grapes at their farm at Pune, Maharashtra, India. Acta Horticulturae. 785: 497-504.

Khan, A.S., Ahmad, N., Malik, A.U., Saleem, B.A. and Rajwana, I.A. 2011. Phenophysiological revelation of grapes germplasm grown in Faisalabad, Pakistan. Int. J. Agric. Biol., 13: 791795.

Kliewer, W.M. and Torres, R.E. 1972. Effect of controlled day and night temperature on grape colouration. Am. J. Enol. Vitic., 23:71-77

Kumar, M. Prasad, Y. Kumar, M. Prakash, S. 
and Kumar, S. 2015. Evaluation of genetic variability, genetic advance, heritability and character association for yield and its contributing traits in Papaya (Carica papaya L.). Vegetos. 28 (2): 99-102.

Mandelli, F., Berlato, M.A., Tonietto, J. and Bergamaskhim. 2003. Phenology of wine grapes in the Seera Gaucha region. Pesquisa Agropecuaria Gaucha. 9:129 $-144$

Mattheou, A., Stavropoulos, N., and Samaras. S. 1995. Studies on table grape germplasm grown in Northern Greece. II. Seedlessness, berry and must characteristics. Vitis. 34 (4), 217-220.

Pina, S. and Bautista, D. 2006. Evaluation of vegetative growth on several table grape cultivars under semiarid tropic conditions in Venezuela. Rev. Fac. Agron., (LUZ). 23: 402-413

Ratnacharyulu, S.V. 2010. Evaluation of coloured grape varieties for yield, juice recovery and quality. M.Sc. Thesis. Andhra Pradesh Horticultural University, Rajendranagar, Hyderabad, A.P.

Romeyer, F.M., Macheix, J.J., Goiffon, J.P., Reminiak, C.C. and Sapis, J.C. 1983. The browning capacity of grapes. changes and importance of hydroxycinnamic acid tartaric acid esters during development and maturation of the fruit. J. Agric. Food chem., 31: 27-34.

Shikhamany. http://www.fao.org/docrep/003/x6897e/ x6897e06.htm.

Shinde, A.K., Burkondkar, M.M., Bhingarde, R.T., Waghmare, G.M., Rangwala, A.D. and Wagh, R.G. 2001. Heat unit requirement for fruit maturity in mango varieties. Indian. J. Plant. Physiol. 6:194-196.

Thakur, A., Arora, N.K., and Singh S.P. 2008. Evaluation of Some Grape Varieties in the Arid Irrigated Region of Northwest India. Acta Hort., 785: 79-83.

Uddin, M., Shah, M., Rahman, K., Alam, R. and Rauf, M.A. 2011. Evaluation of local and exotic grapes germplasm at Mingora, Swat. Sarhad J. Agric., 27(4): 553-556.

Walker, R.R., Read, P.E. and Blackmore, D.H. 2000. Rootstock and salinity effects on rates of berry maturation, ion accumulation and colour development in Shiraz grapes. Australian J. Grape Wine Res., 6: 227 - 239.

\section{How to cite this article:}

Nitin Soni, Prakash Patil, K.C. Meena, Ajay Haldar, Dharmendra K. Patidar and Rajesh Tiwari. 2019. Evaluation of Different Coloured Varieties of Grapes under Nontraditional Area of Malwa Plateau: A Thin Line Tool for Doubling the Farmer Income. Int.J.Curr.Microbiol.App.Sci. 8(03): 1968-1976. doi: https://doi.org/10.20546/ijcmas.2019.803.234 